\title{
Presentación
}

\section{At the Margins: Challenges for Sociologists of Education in Southern Europe}

\author{
En los márgenes: Desafíos para las sociólogas y los sociólogos \\ de la educación en el sur de Europa
}

Mariagrazia Santagati, Rita Bertozzi, José Beltrán Llavador and Alícia Villar-Aguilés

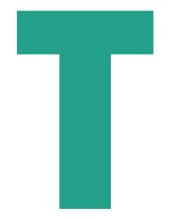

he aim of this special issue of the n. 3/2019 of RASE published in cooperation with the Italian Journal of Sociology of Education, is to reflect on Sociology of Education from a Southern European perspective. Undoubtedly, the starting point is the well-consolidated international debate on the so-called "Theories of the South" (Connell, 2007) or "Epistemologies of the South" (Santos, 2014), and the call for a "Global Sociology" (Burawoy, 2016) also in a postcolonial perspective (Bhambra, 2014). These approaches have made visible the need to seek new theoretical and empirical contributions to think about the social realities of the Global South outside the Euro-American area, which has arisen during the last 40 years in response to social movements and the emergence of different sociological voices all around the world.

We believe it is time to consider whether a Southern analysis of educational problems should be suggested, both at the European level and in each country of the EU, considering the many 'Souths' within the 'Norths'. We would not like to foster North-South divisions inside or outside the scientific community or social life. On the contrary, we propose to discover and widen the possibilities of international dialogue among sociologists of education, deconstructing and going beyond this presupposed divide.

Southern Europe, like all regions of the world, is affected by a rapid and intense process of globalization. Additionally, it is not immune to the global crisis and its various and serious implications such as increasing poverty, climate change, the migrants and refugee's emergency, democratic deficiency, resurgence of populism, civic and moral crisis. Surprsingly, the Mediterranean area has been represented as the most lethal border in the world (Massari, 2017), a contradictory space that seems very far from the idea of intercultural dialogue and pluralism, openness and solidarity, cultural mix and local development, that some sociologists built only ten years ago (Cassano, 2009; Canta, 2010).

It is worth considering that, during the last decade, sociologists of education, especially in Italy, have not paid explicit attention to the Southern or Mediterranean context (Landri, 2008; Mongelli et al., 2012; Colombo et al., 2016), although broader analysis in this direction was carried out in other countries. Many projects and scholars (Santos, 1998; Capucha et al., 2016; Mayo, 2006; Cueca, 2014; Teodoro, 2019) have looked at educational inequalities in Southern Europe, considering it as a territory amongst other Souths, a metaphor of disadvantaged and excluded groups from the benefits of neoliberal globalisation present also in Europe (Sultana, 2012). In this frame, perhaps, the focus on socio-educational problems in

\footnotetext{
Mariagrazia Santagati, Università Cattolica del Sacro Cuore, mariagrazia.santagati@unicatt.it; Rita Bertozzi, Università degli Studi di Modena e Reggio Emilia, rita. bertozzi@unimore.it; José Beltrán Llavador, Universitat de València, jose.beltran@uv.es; Alícia Villar-Aguilés, Universitat de València, alicia.villar@uv.es.
} 
Southern Europe has been considered too narrow or of minor importance. However, it proposes again in new terms the crucial dilemma between guaranteeing equal opportunities and recognising individual diversities through the educational system (Besozzi, 2006).

Facing old questions linked to the process of democratisation of the educational system and to the persistence of inequalities in education, this special issue aims at focusing both on the margins of Europe and on the groups at risk of marginalisation from education, posing these topics at the centre of sociology of education. For this reason, in the title of this Editorial we use the phrase "at the margins" (Llavador, 2004), with an expression that evokes the spatial position (at the margins of Europe), the social condition of disadvantaged groups in the educational field, and the "peripheral" role of sociologists of education in this debate, underlying difficulties and challenges for our discipline (and social sciences in general) in Southern contexts.

From an experiential point of view, this cross-national special issue is made possible thanks to a growing scientific exchange among Southern European sociologists of education. Several meetings and discussions facilitated this international dialogue. Among them, we may mention:

- In Europe, the importance of this debate is reflected in the Research Network (RN 27), Southern European Societies, of the European Sociology Association (ESA) which in turn takes the form of initiatives such as the Working Group (GT 11-FES) of the Spanish Sociology Federation, which recently held its XIII Spanish Conference of Sociology (Valencia, July 2019).

- the conferences and seminars promoted by AIS-Education Section (i.e. Challenges of Education in the Mediterranean Area, University of Bari, Oct 2011; News from the South, Empowerment and Education in Southern Europe, Università Cattolica del Sacro Cuore, Milan, Sept 2016, within the Mid-term Conference of ESA RN10 Sociology of Education);

- the participation of members of AIS-Education to the "Conferencia Ibérica de Sociología de la educación" (Cordoba, 2017), organized by the Education Section of the Spanish and Portuguese Association of Sociology;

- the presence of Spanish and Portuguese colleagues at the First International Conference of "Scuola Democratica. Learning for Democracy" (Cagliari, June 2019).

This scientific and cooperative pathway will lead us to another important event under construction: the next "Southern Conference of Sociology of Education" (Milan, 25-26th May, 2020) with the official participation of the sociological association of France (AFS-RT Sociologie de l'éducation et de la formation), Italy (AIS-Educazione), Portugal (APS-ST Sociologia da Educação), and Spain (FES-GT13 Sociología de la Educación).

During this fertile dialogue among sociologists of education, simple but important questions have emerged. Can we identify common or different educational questions in Southern European contexts? Can we share any common interpretive frameworks for a better understanding of education in these societies? Can we imagine common or different solutions for the same educational problems?

Perhaps this issue represents too much ambition in the attempt to look for some shared answers, identifying socio-educational phenomena both studied or yet to be studied, theoretical or methodological options analysed or to be further deepened and spread, some policy challenges to be delineated and faced. A consolidated field of analysis does not exist yet (at least in Italy) among sociologists of education but 
the idea is to first step in this direction and to shed light on possible emerging trends, in order to identify new issues for the research agenda.

The following papers bring together a set of views on some characteristic and relevant phenomena that have received constant attention in the field of the Sociology of Education in Spain, namely: the persistence of social inequalities and their effects on education; the correlation between social class and educational transitions from the first educational levels, the role of expectations in tracing or interrupting academic trajectories; reflectivity on the disciplinary field of the sociology of education itself, that is, the need to know the interests and research outcomes of those of us who are involved in analysing the social dimension of education; the analysis of the way in which measurement and evaluation procedures employed to assess the scientific production in the field of Sociology of Education operate, etc. Even if these topics do not cover the whole range of interests and are not fully representative of all of them, they are nonetheless significant as case studies whose meaning is broadened when interpreted in the context of Southern European countries.

Finally, both the interview with Carlos Alberto Torres and António Teodoro's comments enrich the perspectives on Southern Europe, as they offer views where the global and the local are intertwined. Their texts are dialogically engaged with Vincenza Pellegrino and Peter Mayo's contributions in the IJSE.

This monographic issue seeks to build bridges with what lies beyond our borders, and it is an open invitation to start a conversation from the lens of the Sociology of Education discipline about common concerns and commitments within a context of increasing levels of collaboration.

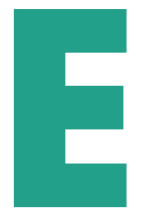

1 objetivo de este número especial de la Revista de la Asociación de Sociología de la Educación (RASE), publicado al mismo tiempo que el vol. 11, n. 3, octubre 2019, de la IJSE (Revista Italiana de Sociología de la Educación; Italian Journal of Sociology of Education, por su denominación original en inglés), es reflexionar sobre la Sociología de la Educación desde una perspectiva del sur de Europa. Sin duda, el punto de partida es el bien consolidado debate internacional sobre las denominadas «Teorías del Sun» (Connell, 2007) o «Epistemologías del Sur» (Santos, 2014), y la invocación a una «Sociología Global» (Burawoy, 2016) también desde una perspectiva postcolonial (Bhambra, 2014). Estos enfoques han hecho visible la necesidad de buscar nuevos aportes teóricos y empíricos para pensar en las realidades sociales del Sur Global más allá del área euroamericana, surgidas en los últimos 40 años como respuesta a los movimientos sociales y al surgimiento de diferentes voces sociológicas en todo el mundo.

Creemos que es hora de considerar si se debe sugerir un análisis de los problemas educativos del Sur, tanto a nivel europeo como en cada uno de los países de la UE, teniendo en cuenta los muchos «Sur» dentro de los «Nortes». No queremos fomentar las divisiones Norte-Sur dentro o fuera de la comunidad científica o de la vida social. Por el contrario, proponemos descubrir y ampliar las posibilidades de diálogo internacional entre sociólogos de la educación, deconstruyendo y superando esta división presupuesta.

El sur de Europa, como todas las regiones del mundo, se ve afectado por un rápido e intenso proceso de globalización. Además, no es inmune a la crisis mundial y a sus diversas y graves implicaciones, como el aumento de la pobreza, el cambio climático, la emergencia de los migrantes y refugiados, la deficiencia democrática, el resurgimiento del populismo y la crisis cívica y moral. Sorprendentemente, el área mediterránea ha sido representada como la frontera más letal del mundo (Massari, 2017), un espacio contradictorio que parece muy alejado de la idea de diálogo intercultural y pluralismo, apertura y solidaridad, 
mezcla cultural y desarrollo local, que algunos sociólogos construyeron hace solo diez años (Cassano, 2009; Canta, 2010).

Vale la pena considerar que, durante la última década, los sociólogos de la educación, especialmente en Italia, no han prestado atención explícita al contexto meridional o mediterráneo (Landri, 2008; Mongelli et al., 2012; Argentin et al., 2016), aunque en otros países se ha llevado a cabo un análisis más amplio en este sentido. Muchos proyectos y estudiosos (Santos, 1998; Capucha et al., 2016; Borg \& Mayo, 2006; Cueca, 2014; Teodoro, 2019) han analizado las desigualdades educativas en el sur de Europa, considerándolo como un territorio entre otros del Sur, una metáfora de los grupos desfavorecidos y excluidos de los beneficios de la globalización neoliberal presente también en Europa (Sultana, 2012). En este marco, quizás, el enfoque de los problemas socioeducativos en el sur de Europa se ha considerado demasiado especializado o de menor importancia. Sin embargo, vuelve a proponer en nuevos términos el dilema crucial entre garantizar la igualdad de oportunidades y reconocer las diversidades individuales a través del sistema educativo (Besozzi, 2006).

Frente a las viejas cuestiones vinculadas al proceso de democratización del sistema educativo y a la persistencia de las desigualdades en la educación, este número especial pretende centrarse tanto en los márgenes de Europa como en los grupos en riesgo de marginación de la educación, situando estos temas en el centro de la Sociología de la Educación. Por ello, en el título de este editorial utilizamos la expresión «en los márgenes» (Beltrán Llavador, 2004), con una expresión que evoca la posición espacial (al margen de Europa), la condición social de los grupos desfavorecidos en el ámbito educativo y el papel «periférico» de los sociólogos de la educación en este debate, las dificultades y los retos subyacentes para nuestra disciplina (y las ciencias sociales en general) en los contextos del Sur.

Desde el punto de vista de la experiencia, este número especial internacional es posible gracias a un creciente intercambio científico entre sociólogos de la educación del sur de Europa. Varias reuniones y debates facilitaron este diálogo internacional. Entre ellos, enumeramos los siguientes:

- En Europa, la importancia de este debate se refleja en la Red de Investigación (RN 27), Sociedades del Sur de Europa, de la Asociación Europea de Sociología (ESA), que a su vez toma la forma de iniciativas como el Grupo de Trabajo (GT 11-FES) de la Federación Española de Sociología, que recientemente celebró su XIII Congreso Español de Sociología (Valencia, julio de 2019).

- Las conferencias y seminarios promovidos por la Sección de Educación del AIS (es decir, Desafíos de la Educación en el Área Mediterránea, Universidad de Bari, octubre de 2011; Noticias del Sur, Empoderamiento y Educación en el Sur de Europa, Università Cattolica del Sacro Cuore, Milán, septiembre de 2016, en el marco de la Conferencia Intermedia de la ESA RN10 Sociología de la Educación);

- La participación de los miembros de AIS-Education en la «Conferencia Ibérica de Sociología de la Educación» (Córdoba, 2017), organizada por la Sección de Educación de la Asociación Española y Portuguesa de Sociología;

- La presencia de colegas españoles y portugueses en el I Congreso Internacional de «Scuola Democratica. Aprendizaje para la democracia» (Cagliari, junio de 2019).

Este itinerario científico y cooperativo nos llevará a otro importante acontecimiento en construcción: la próxima «Conferencia Sur de Sociología de la Educación» (Milán, 25-26 de mayo de 2020) con la par- 
ticipación oficial de la Asociación Francesa de Sociología (AFS-RT Sociologie de l'éducation et de la formation), Italia (AIS-Educazione), Portugal (APS-ST Sociologia da Educação), y España (FES-GT13 Sociología de la Educación).

Durante este fecundo diálogo entre sociólogos de la educación, han surgido preguntas sencillas pero importantes. ¿Podemos identificar cuestiones educativas comunes o diferentes en los contextos del sur de Europa? ¿Podemos compartir marcos interpretativos comunes para una mejor comprensión de la educación en estas sociedades? ¿Podemos imaginar soluciones comunes o diferentes para los mismos problemas educativos?

Quizás esta publicación representa demasiada ambición en el intento de buscar algunas respuestas compartidas, identificando fenómenos socioeducativos tanto estudiados como por estudiar, opciones teóricas o metodológicas analizadas o por profundizar y difundir, algunos retos políticos a ser delineados y enfrentados. Todavía no existe un campo de análisis consolidado (al menos en Italia) entre los sociólogos de la educación, pero la idea es dar un primer paso en esta dirección y arrojar luz sobre posibles tendencias emergentes, con el fin de identificar nuevos temas para la agenda de investigación.

Los artículos que se presentan a continuación reúnen un conjunto de miradas sobre algunos fenómenos característicos y relevantes que han sido objeto de atención constante en el ámbito de la Sociología de la Educación en España, a saber: la persistencia de las desigualdades sociales y sus efectos en la educación; la correlación entre clase social y transiciones educativas desde los primeros niveles educativos, el papel de las expectativas a la hora de trazar o interrumpir trayectorias académicas; la reflexividad sobre el propio campo disciplinar de la Sociología de la Educación, esto es, la necesidad de conocer los intereses y los trabajos de las y los investigadores que nos dedicamos al análisis de la educación en su dimensión social; los mecanismos con los que opera la medida y evaluación de la producción científica en el campo de Sociología de la Educación, etc. Estos temas no agotan el inventario y no pretenden ser representativos, pero sí resultan significativos como casos de estudio que amplían sus significados desde una interpretación contextualizada en países del Sur de Europa.

Finalmente, tanto la entrevista realizada a Carlos Alberto Torres como el comentario firmado por António Teodoro, enriquecen las perspectivas sobre el Sur de Europa, con contribuciones en las que se entrecruzan las dimensiones de lo global y lo local. Ambos textos entran en diálogo con los comentarios realizados por Vincenza Pellegrino y por Peter Mayo en la revista IJSE.

Con este número monográfico hemos pretendido tender puentes más allá de nuestras fronteras, invitando a una conversación abierta desde la Sociología de la Educación, sobre inquietudes y compromisos comunes, en un contexto de colaboración creciente.

\section{Referencias bibliográficas/Bibliographical references}

Argentin, G.; Colombo, M.: Pandolfini, V. (2016): “La sociologia dell'educazione in Italia: prospettive di ricerca di fronte alla 'riformabilità' dei sistemi educativi” en E. Ruspini \& F. Corbisiero (Eds.). Sociologia del futuro. Studiare la società del ventunesimo secolo. Padova: CEDAM.

Beltrán Llavador J. (2004). Márgenes de la educación. La lucha por la claridad. Valencia: Editorial Germania.

Besozzi, E. (2006). Società, cultura, educazione. Carocci: Roma.

Bhambra, G. (2014). Connected Sociologies. London: Bloomsbury. 
Borg, C. y Mayo, P. (2006): “Challenges for Critical Pedagogy: A Southern European Perspective. Cultural Studies”. Critical Methodologies, 6 (1), 143-154.B

Burawoy, M. (2016): “The Promise of Sociology: Global Challenges for National Disciplines”. Sociology, 50 (5), 949-959.

Canta, C. C. (2010). Seminare il dialogo. Persone e trame del Mediterraneo. Roma: Aracne.

Capucha, L.; Sebastiao, J.; Martins S. da C.; Capucha, A. R. (2016): "Crisis and Education in Southern Europe: The Effects of Austerity and Ideology". Comparative Sociology, 15, 593-620.

Cassano, F. (2009). Il pensiero meridiano. Roma-Bari: Laterza.

Connell, R. (2007). Southern Theory. Cambridge: Polity Press.

Cueca, E. G. (2014): “Aprender del Sur. El pensamiento de Boaventura de Sousa Santos en la transición paradigmática”. Alice Working Paper, 1, CES, Universidade de Coimbra.

Landri, P. (2008): "The permanence of distinctiveness. Performances and changing schooling governance in the Southern European Welfare States". Mediterranean Journal of Educational Studies, 13 (2), 117-135.

Massari, M. (2017). Il corpo degli altri. Migrazioni, memorie, identità. Napoli-Salerno: Orthotes.

Mongelli, A.: Scardigno, F.: Merico, M. (2012): “The Mediterranean: a Challenge for the Sociology of Education". Italian Journal of Sociology of Education, 2, 1-15. Consultado en http://ijse.padovauniversitypress.it/2012/2/1

Santos, B. de S. (1998). De la mano de Alicia. Lo social y lo politico en la postmodernidad. Santafé de Bogotá: Ediciones Uniandes.

Santos, B. de S. (2014). Epistemologies of the South. London: Routledge.

Sultana, R. (2012): "Learning from the Mediterranean: the return of the political and an education in hope". Italian Journal of Sociology of Education, 4(2), 21-39. Consultado en http://ijse.padovauniversitypress.it/system/files/papers/2012_2_3.pdf.

Teodoro, A. (2019): "The end of isolationism: examining the OECD influence in Portuguese education policies, 1955-1974”. Paedagogica Historica, DOI: https:/ / doi.org/10.1080/00309230.2019.1606022 